\title{
IMPACT OF SIZE AND QUALITY OF GOVERNMENTS ON HAPPINESS; FINANCIAL INSECURITY AS A KEY-PROBLEM IN MARKET-DEMOCRACIES
}

\author{
Review of "The Political Economy of Human Happiness" by Benjamin Radcliff, \\ Cambridge University Press; 2013, ISBN 978-1-107-03084-8 \\ Jan Ott, Erasmus University Rotterdam, Netherlands \\ ott@ese.eur.nl
}

\begin{abstract}
If I agree to do a job for a friend for \$100, my friend and I would get very upset if someone else would put his hands on our shoulders, telling us that he wants a 20\% Value Added Tax and $25 \%$ Income Tax of the remaining \$80, \$40 altogether. Perhaps we would cool down a bit if he would be a nice guy and if he would tell us some reasonable story about all the good things he wants to do with our money. But we would still be rather upset and critical. Benjamin Radcliff however, argues that there is a positive relation between the size of governments, as expressed in expenditures and taxation, and average happiness in nations. His conclusion is counterintuitive but nevertheless convincing, in particular by his excellent statistical analysis of available data. His argument would have been even more convincing, if he would have focused a bit more on his key-problem: poverty and financial insecurity in free-market societies. This problem can be solved by a gradual introduction of a basic income, in combination with more political attention for the distribution of labour in society. Work has to be done by somebody! He also should have paid more attention to the quality of governments as a necessary condition for his argument, and he should have acknowledged that even a small government can be very effective. Big government is neither required nor sufficient for happiness! In this article Radcliff's argument will be summarized first, followed by some critical comments.
\end{abstract}

Key-words: Happiness - Labour Unions - Quality of Governments - Size of Governments Tri- and bipartite consultations between governments, employers, and labour unions

\section{Short summary of Radcliff's book}

\subsection{How to pursue happiness?}

Ben Radcliff observes that in the American Declaration of Independence of 1776, people are entitled to institute and organize governments in such forms '.... as to them shall seem most likely to effect their Safety and Happiness'. This principle became widely accepted, but what should governments do to maximize happiness. Should they leave it to free markets or should they use the power of the state to do something additional? People with property embrace free markets as a central organizing principle. They want governments to protect property rights and are suspicious about democracy, because they fear levelling tendencies. This view has been developed and defended by James Madison. Other people are sympathetic to the idea that a reduction of poverty and inequality, to create more happiness, is a legitimate task for governments. In 'The Rights of Man' Tom Paine argues for a "social wage", a basic level of income provided by the state for those who are incapable of providing for themselves. The state should also provide free education and should pursue full 
employment. Such views refer to the key-issue in the continuous debate: whether to protect markets against politics, or to make markets subject to politics. Radcliff wants to answer this question by an evaluation of the impact of government activities on happiness, but he evaluates first some popular arguments in this debate.

\subsection{Arguments against government activities: inefficiency and immorality}

The most general argument against government activities is 'efficiency', essentially implying a maximum output with a certain amount of resources. A more specific meaning is Pareto-efficiency or -optimality, which is achieved if there are no possibilities to make somebody better off, without making someone else worse off. Free markets, undisturbed by government activities, are often supposed to be the best guarantee for such efficiency. Friedrich von Hayek (1944) is a strong defender of free markets. In his view attempts to change the outcomes are doomed, because nobody can obtain the required information for success. In his view there will always be "unintended consequences", whose negative effects will outweigh whatever positive effects. Radcliff is not convinced. In his view research and literature are quite clear about the seriousness of 'market failures' and the need of solutions. According to Greenwald and Stiglitz (1986, Stiglitz 1994) 'market failure' is not exceptional but standard, so that government activities are always needed to achieve efficiency. This proposition, that free markets do not produce efficient outcomes, is not really disputed within the field of economics.

Radcliff is also sceptical about the argument that government activities have a negative impact on the economy and on economic growth. The Nordic countries, with high levels of public spending, rank high in economic competitiveness and demonstrate that a generous universalistic welfare state is not incompatible with a dynamic market economy. A principal reason is that public spending is conducive to the effective operation of a market economy. High levels of taxation and spending do not serve to depress economic performance (North, Wallis, and Weingast, 2009).

There are also moral arguments against the welfare state. Charles Murray (1984) maintains that even a minimalist welfare state creates disincentives for people to work and to behave responsibly. A popular example is the discouragement of marriage by financial benefits for "unwed mothers". Radcliff finds no support for this argument in the literature. The literature confirms that welfare programs reduce levels of poverty (Kenworthy, 1999). Another moral argument is that the welfare state delegitimizes other institutions essential to human well-being, like the family and the church. This argument is based on the assumption that the more systematic welfare provided by the state, is of a lower social quality than the social support provided by civil society institutions, like the family and the church. Radcliff sees no justification for this assumption.

\subsection{Is efficiency an acceptable standard?}

In addition to that Radcliff finds it clear that 'efficiency' as such is not a normative acceptable standard by definition. Society might well decide that a modestly lower level of production is acceptable, if it allows for a higher level of well-being. This idea would be inconceivable for von Hayek, because in his view non-market authority structures, like democracy, economic regulations, the welfare state and labour unions, are coercive institutions that maintain themselves at the expense of those they are supposed to serve.

Radcliff is more optimistic about the role of such institutions. Through labour unions workers are able to improve their position by bargaining collectively over wages and working conditions. They can establish rules that limit the authority of employers to dismiss employees arbitrarily. These conditions have three important consequences; they improve the 
standard of living, they provide the psychological benefit of some degree of job security, and they reduce the extent to which workers are powerless and voiceless. Once established, unions also become a political resource for workers, particularly when they coordinate their activities through federations. Such federations can use their financial and human resources to facilitate the creation and election of political parties committed to their interests. This political power can also manifest itself in a welfare state that provides income maintenance for the unemployed, pensions for the elderly, and a variety of noncash benefits, such as medical insurance, to which everyone in society is entitled.

The value for human well-being is clear for Radcliff: people who enjoy a higher standard of living, who work in more agreeable circumstances, who are more secure and who feel that their dignity as a person is respected are more likely to enjoy rewarding lives.

Radcliff makes it clear that authors like Putnam, Lane and Layard underestimate the crucial importance of having and keeping some paid job in the first place, if they suggest that people just have to put more priority on their social relations and less priority on their work.

It is tempting to think this is just about economics, but in Radcliff's view to do so is to miss the connection between the economic and the personal. Although it is true that money buys neither friendship nor love, it remains the case that financial security and a satisfying work life make these valuable things easier to find and maintain. The individual who is relatively affluent and who is, above all, secure in maintaining that affluence, finds it easier to be a good friend or a good spouse.

For Radcliff the reason is obvious: economic deprivation, or the imminent fear of it, imposes psychological costs, such as anxiety and stress, introversion, pessimism, neuroticism and loss of self-esteem (e.g. Diener et al., 1999). Although it is sometimes convenient to conceive of some of these characteristics as personality traits, they are surely inhibited or promoted by one's life experiences. Thus as Lane (2000) puts it, they are "malleable" aspects of the human personality, being largely a product of the material circumstances of life, and thus of socio-political structures that affect those circumstances.

Apparently Radcliff has his views on such arguments, but he wants to assess the balance of the positive and negative effects of government activities on happiness empirically. As he puts it: reasonable individuals will differ as long as they are limited to abstract debates, such endless debates can only be decided by an empirical test.

\subsection{The Scientific Study of Happiness}

Radcliff makes an inventory of the state of the art in happiness research. Happiness can be measured without serious problems in terms of validity, reliability, and comparability across countries. In general people know how much they enjoy their lives and they can answer questions about their enjoyment. Their answers are not unduly contaminated by social desirability.

There are two seemingly contradictory theories about happiness: the 'bottom-up-theory' and the 'top-down-theory'. In the 'bottom-up-theory' happiness is supposed to be determined by events and situations external to the individual's inner mental processes. In this view happiness will be affected by observable characteristics of the individuals and by their sociopolitical environment. This view is associated with the idea that happiness is determined by the extent to which universal human needs are met (Veenhoven, 2009).

A 'top-down-theory' suggests just the opposite: happiness is a product of the individual's inner psychological processes; people are supposed to have an internal happiness level that colours their day-to-day experiences. There are a variety of such theories. If taken to their logical extreme these theories imply that happiness is not a function of the outside world, so 
that attempts to make the world better, whether by the political program of the Left or the Right, are doomed to failure.

According to Radcliff we are not faced with a choice between these two theories. Our evaluation of life can be determined in part by both top-down and bottom-up processes. We can admit that individuals may have some disposition toward a certain level of happiness, while still maintaining that the structure of society is also important. Happiness is partially determined by relatively fixed personality traits, like extroversion, neuroticism, optimism, self-esteem and efficacy, and at the same time by conditions external to the individual.

But there is a deeper point as well. As observed by Lane (2000) personality traits are not unalterable or immutable: people can become more or less optimistic, more or less introvert, and so on. Personality can develop and grow, particularly when conditions of life encourage such growth. For instance, the New Deal program that offered hope in the face of the deprivation of the Great Depression surely increased optimism while decreasing extreme anxiety and worry ('neuroticism'). The idea that personality traits can be changed is the same common sense that motivates the 'positive psychology', which attempts to provide individuals with practical strategies for achieving greater happiness, whatever their personalities.

In Radcliff's view happiness is thus best conceived of as something that emerges from a combination of our life experiences and the interaction between those experiences and particular aspects of our personality.

\subsection{The Size of government and happiness}

Radcliff apparently assumes that the level of government activities is related to the size of government, so he considers the question: "Does 'big government' improve or impoverish human life?" The size of government can be conceived of as having three aspects.

First: the scope of the welfare state which directly transfers income from its free market distribution to a politically determined distribution. There is however some scepticism about the ability to rely on such expenditure levels. Esping Andersen has developed a more precise measure, a summary index that assesses the extent of social insurances in three specific domains: pensions, income maintenance for the ill or disabled, and conventional unemployment benefits. Radcliff uses this 'decommodification index' ${ }^{1}$ and the 'generosity index' as developed by Scruggs (2005) which are more sensitive to the real impact of welfare-programs on citizens. In addition to that he uses 'social spending', defined as the total of public spending, including publicly mandated spending in the private sector.

The second aspect of 'big government' comprises the multitude of other state activities beyond simple redistribution, like support for education, housing and national health. The magnitude of such activities is reflected in government consumption, as a percentage of total national consumption.

The third aspect is the tax burden that the state imposes on society. From this last perspective we can place societies along a dimension in which one end is a purely 'socialist' economy implying one-hundred percent taxation and the other a purely libertarian one having zero taxation.

Radcliff analyses the statistical relations between these indicators for the size of governments and happiness in 21 traditional member states of the OECD in different years. His results are indeed convincing. There is a clear positive relation between these sizeindicators and individual and average happiness in nations (data World Values Surveys 19812007). A remarkable result is that these positive correlations are similar for specific groups like men and women, and people with a high and a low income. Radcliff also observes that 
his results are robust and that the positive relationship is not a consequence of a 'reversed causality' of happiness on government activities.

Radcliff also looks at the impact of labour unions and economic regulation on happiness. He expects a positive impact and this appears to be the case indeed. There is at least a clear positive relation between individual and average happiness on the one hand and on the other hand union density and Employment Protection Legislation (EPL, developed by the OECD). It is remarkable again that this positive correlation is very similar for different groups, like union members and other employees, and people with a high or a low income.

Radcliff also compares level of government activities and individual and average happiness-levels in 48 American States. The results are very similar. The differences in state activities, as expressed in transfer payments, economic regulation, government ideology, democratic party control and union density, are less substantial as the differences between the 21 OECD-nations, but such differences still go together with substantial differences in individual and average happiness.

\section{Comments}

\subsection{Message is convincing}

Radcliff's key-message in this book is that the level of government activities, as expressed in some size-indicators, and labour unions create some protection against the negative impact on happiness of poverty, unemployment, and financial insecurity in general. This message is indeed convincing.

His statistical analysis, including many controls, robustness-checks and discussions of potential objections, is comprehensive and straight-forward. His analysis is facilitated by the homogeneity in his sample of 21 OECD-nations in different years. These countries are rather comparable and his regressions produce stable coefficients. His message is also supported by the substantial correlations, found by Gallup, between financial insecurity and negative feelings like stress and depression.

His specific conclusions about the positive role of labour unions are also consistent with many observations about the importance of bi- and tripartite consultations between governments, labour unions and employers-organizations. The International Labour Organization has produced some relevant publications at this point (ILO, 1996). In tripartite consultations agreements can be made to keep wage-increases within certain limits, and to spend money instead for matters like training on the job, employability, research and development, and the creation of additional employment for minorities and people with some physical or mental handicap. Such agreements contribute substantially to the macro labourproductivity, competitiveness, and economic development. They also minimize economic damage by conflicts and strikes.

Another advantage is that labour unions and employers can make collective labour agreements which can be supported by national legislation, and which can be used, if they work out well in practice, as examples for national legislation ${ }^{2}$. Such interactions between collective agreements and national legislation contribute to tailor-made regulations in specific sectors of industry, and to institutional quality and social trust in general.

\subsection{Quality of government is necessary}

In a world-wide sample of 130 nations Ott (2010) shows that there is indeed a positive relation between the size of government and happiness, but only if the technical quality of governments is high. This technical quality is assessed by taking the average of the scores of the World Bank (Kaufman et al. 2008) for Rule of Law, Government Effectiveness, Control 
of Corruption and Regulatory Quality. The Democratic Quality is the average of the scores for Voice and Accountability and Political Stability ${ }^{3}$. If the technical quality is low then there is no positive relation, or even a negative one. Many (ex-) communist countries had, and often still have, big but low quality governments and low levels of happiness. Ott finds, on the other hand, that there is always a positive relation between the quality of governments and happiness, independent of size. Small governments can be very effective indeed, also in terms of happiness, by intelligent legislation and co-operation, not only with labour unions and employers, but also with other civil-society organizations like insurance companies and specific interest groups. In a nutshell: the impact of size on happiness depends on quality, but the impact of quality on happiness is independent of size.

Radcliff, on the other hand, is somewhat easy-going about the importance of quality, even though he admits that governments have to be effective, not corrupt and democratic. His main argument is that the quality of governments, as measured by the Government Indicators of the World Bank, is measured in a very broad way by 25 different variables with data from many sources. In his view it is difficult to interpret the results.

At this point he is too pessimistic. There is a high consistency between the six government indicators and in particular between the four indicators for the technical quality. It is quite clear that these indicators measure some unobserved factor, probably closely related to the behaviour and the general attitude of government representatives and civil servants. A closer look on the indicators also reveals that these indicators are very balanced, in the sense that a high quality, as measured by these indicators, is beneficial for all citizens. Rich citizens benefit perhaps a bit more from stability and market-enhancing institutions, as measured by Political Stability, Rule of Law, and Control of Corruption, but poor citizens and minorities benefit a bit more from possibilities to change the existing order, as measured by Voice and Accountability, Government Effectiveness, and Regulatory Quality.

Radcliff is also critical about the Government Indicators since a high level of government activities is interpreted as a negative sub-indicator for quality. This is true, but this is only a minor element in one of the many sub-indicators, delivered by one of the many data-sources (the Heritage Foundation). Radcliff's objection is correct, but certainly not good enough to disqualify the assessments of the World Bank ${ }^{4}$.

Radcliff's undervaluation of quality is not harmful for his argument, since he uses a small sample of 21 traditional OECD-countries (in different years) and correctly observes that the government-quality in these countries is good and that the differences are small. In more comprehensive world-wide samples these differences are more substantial and influential. The fact that there is a strong autonomous relation between the technical quality of governments and average happiness, Radcliff's normative standard, should have warned him to be more attentive about the importance of government quality in general!

\subsection{Terminology is woolly and at some points inaccurate}

The message is convincing, but Radcliff's terminology is woolly and at some points inaccurate. Radcliff describes how the essential feature of free markets, the 'commodification of labour' (see footnote 1), produces first an 'inevitable' division of society in two classes, a class of capital owners and a class of people without capital ${ }^{5}$. The relations between representatives of these classes are 'asymmetrical' because capital owners can choose whether they want to work or not, and can choose whether they want to employ workers or not. People without capital have no choice; they have to work in order to survive. Capital owners 'expropriate' some 'surplus wealth' of workers. This 'surplus wealth' is the difference between the actual level of economic production and the amount required for the 'subsistence of the workforce' ${ }^{6}$. Capital owners can dispose of this surplus in any way they want to. 
This language is woolly and too simple for the present. It is, in particular, no longer realistic to make a sharp distinction between people with capital and people without capital. Many people, workers included, have capital and want business to make profits for their pension or otherwise. Radcliff's own observation, that the positive impact of government activities is comparable for different groups of people, is another indication that we should not overvalue differences between 'haves and have-nots'. This language is regrettable, because it makes Radcliff's argument less understandable, and less convincing, for many readers.

\subsection{Is an unconditional basic income a solution?}

This woolly language could have been avoided if Radcliff would have paid more attention to the key-issue in his argument: the negative effects on happiness of poverty and financial insecurity. It is remarkable, in that respect, that Radcliff pays no attention to the possibilities of a social wage or basic income. An unconditional basic income would make it easier for employees to leave unpleasant jobs, and it would reduce poverty and financial insecurity by job-insecurity, or by the unpredictable financial consequences of illness, disability and old age. It would reduce labour costs since people would be willing to work for lower wages, and it would stimulate employers to treat employees with respect. The relations between employers and employees would become more 'symmetrical' in Radcliff's terminology! A basic income would also create possibilities to simplify existing systems of income-security.

There is however one problem that deserves our attention: a basic income implies that people can survive without a paid job and this can lead to problems on the labour market. Who will do the dirty and unpleasant work, if there is an unconditional basic income? Such problems may also occur if social security would be more generous and easier to obtain, as Radcliff seems to propose. Making the dirty work less dirty and the unpleasant work less unpleasant would certainly help.

But is this enough? Perhaps we will also have to accept that money can no longer be the dominant steering principle on the labour market. Maybe we should create more room for alternative motivators, like social obligations and personal challenges as defined by the people themselves. For national and local governments this may require more attention for volunteer work and for combinations of paid work with personal care, within the family or in the neighbourhood, like for children, the sick, the disabled and the elderly. Some coordination by local government agencies and civil society may be needed. In sum: maybe the moneyeconomy has reached its limits, and perhaps people will have to learn again to do things without getting paid for it! As they did in the old days!

\section{References}

1. Arndt, C. \& Oman, C. (2006). Uses and abuses of governance indicators. The Organization for Economic Cooperation and Development (OECD). Development Centre Studies.

2. Diener, E. et al. (1999). Subjective Well-being: Three Decades of Progress. Psychological Bulletin 125 (2): 276-302.

3. Greenwald, B. and Stiglitz, J. (1986). Externalities in Economies with Imperfect Information and Incomplete Markets. Quarterly Journal of Economics 101 (2), p. 229264.

4. Hayek, F. (1944). The Road to Serfdom. London, Routledge.

5. Helliwell, J.; Huang, H.; How's your government? International evidence linking good governance and well-being. British Journal of Political Science, 38, 595-619. 
6. International Labour Organization (Geneva, 1996). Report (VI) on 'Tripartite consultation on the national level on economic and social policy', also referring to the relevant Convention 144 and Recommendations 113 and 152.

7. Kaufmann, D., Kraay, A., Mastruzzi, M.; Governance Matters VIII, Aggregate and Individual Governance Indicators, 1996-2008. World Bank Policy Research, Working Paper No 4978.

8. Kenworthy, L. 1999). Do Social Welfare Policies Reduce Poverty? A Cross-National Assessment. Social Forces 77 (3): 1119-1139.

9. Khan, M. (2007). Governance, economic growth and development since the 1960s. Desa Working Paper 54. UN, Dept. Economic and Social Affairs, New York.

10. Lane, R. (2000). The Loss of Happiness in Market Democracies. New Haven, CT. Yale University Press.

11. Murray, C. (1984). Losing Ground: American Social Policy, 1950-1980. New York, Basic Books.

12. North, D.; Wallis, J. and Weingast, D. (2009). Violence and Social Orders. Cambridge University Press.

13. Ott, J. (2010). Good Governance and Happiness in Nations: technical quality precedes democracy and quality beats size. Journal of Happiness Studies, 11 (3), 353-368.

14. Ott, J. (2012). An Eye on Happiness. Happiness as an additional goal for citizens and governments. The Hague, Beta Communicaties.

15. Scruggs, L. (2005). Comparative Welfare Entitlement Dataset. Department of Political Science, University of Connecticut. Assessed April 152005.

16. Stiglitz, J. (1994). Whither Socialism? Wicksell Lectures. Boston, MIT-Press.

17. Veenhoven, R. (2009). How do we assess how happy we are? In Happiness, Economics and Politics, edited by A. Dutt and B. Radcliff, 45-69. Cheltenham, UK; Edward Elgar.

\footnotetext{
${ }^{1}$ The phrase "commodification of labour" refers to the transformation of human labour to a commodity with a certain price, independent of any social context and the needs and wants of the workers. 'Decommodification of labour' is, as defined by Esping Andersen: the degree to which individuals or families can uphold a socially acceptable standard of living independent of market participation.

${ }^{2}$ A well-known example: some collective contracts in the Netherlands facilitate the combination of having a job and taking care for children (and sometimes for relatives who need some personal care temporarily), with some regulations for parental leave and part-time jobs. Since these regulations appeared to be appreciated they were incorporated in national legislation. Such regulations obviously contribute to happiness and macro-productivity. In order to respect more specific regulations in collective contracts for sectors of industry or individual companies, many regulations at a national level can be ignored if these collective contracts are more beneficial for employees.

${ }^{3}$ Helliwell and Huang (2008) make the same distinction but speak instead about the 'GovDem-' and 'GovDoelements' of Government-quality.

${ }^{4}$ There has been some more substantial criticism on these assessments, as by Arndt and Oman (2006) and Khan (2007). For a discussion of such issues see "Government Indicators: Where are we, where should we be going?" by Kaufmann and Kraay (2008) and Ott (2012).

${ }^{5}$ Radcliff observes that free markets did not change the historical fact that there is always some 'kleptocracy' at work: an elite segment of society, like a pharaoh or king and their families, or some nobility or clergy, expropriating some surplus wealth of other people.

${ }^{6}$ This extraction of surplus may have positive consequences by the creation of collective goods, like physical or social infrastructures that contribute to the general quality of life.
} 